Journal of Agrometeorology 23 (2) : 200-206 (June 2021)

\title{
Population dynamics of aphid and coexisting predators in tomato agroecosystem
} SHIVANI KHOKHAR*1 and KRISHNA ROLANIA

\author{
Department of Entomology, CCS HAU, Hisar, India \\ ${ }^{1}$ Department of Entomology, PAU, Ludhiana, India \\ *Corresponding author: shivanikhokhar08@yahoo.in
}

\begin{abstract}
Aphids generally attack vegetative plant parts, preferably leaves, and devitalize the plant by sucking the cell sap. Thorough knowledge of pest-predator ecology and their interaction is requisite to initiate timely pest management strategies. Therefore, we aimed to study the population dynamics of aphids and their predators on tomato in Hisar, Haryana during Rabi, 2016-17 and 2017-18. We observed two dominant aphid species viz., Aphis gossypii and Myzus persicae and three aphidophagous predator groups viz., coccinellids, spiders and syrphid fly maggots in the tomato agroecosystem. Aphid infestation started during the 9th standard meteorological week (SMW) and attained a peak during the 12th SMW (22.65 aphids per three leaves per plant). Aphid population exhibited highly significant negative correlation with minimum temperature $\left(r=-0.917^{* *}\right)$, maximum temperature $\left(r=-0.895^{\star \star}\right)$ and wind speed $\left(r=-0.809^{* \star}\right)$. However, it was positively correlated with morning relative humidity $\left(r=0.933^{* *}\right)$ and evening relative humidity $\left(r=0.856^{* *}\right)$. We used Principal component analysis (PCA) to reduce the dimensions of data and variables were transformed into principal components $(\mathrm{PC})$ to explain the nature and extent of the relationships among different variables. PC1 and PC2 capture 57.6 and $20.3 \%$ of the variability in the data, respectively. Aphid predators exhibited a significant positive correlation with the prey population suggesting a positive density-dependent response.
\end{abstract}

Key words: Aphis gossypi, coccinellids, Myzus persicae, predators, regression, tomato

Tomato (Solanum lycopersicum Mill) is the second most important vegetable crop after potato (FAOSTAT, 2018). Globally, tomato production stands at 182.26 million tonnes (mt) from 4.76 million hectares (mha) (FAOSTAT, 2018). India is the second-largest producer of fresh tomatoes after China (61.63 mt) and ensures a total production of 19.37 mt from 0.79 mha (FAOSTAT, 2018). Tomato productivity is hampered by several abiotic and biotic stressors such as unfavourable environment, degraded soils, weeds, insectpests and diseases (Osei et al., 2010). Global crop losses owing to pest infestation are appraised to be around $34.4 \%$ of attainable tomato yield and without crop protection measures losses would escalate to 77.7\% (Zalom, 2003). Aphids generally attack all the vegetative plant parts in larger numbers, settle down on the underside of leaves and suck the cell sap from phloem sieves (Watt \& Hales, 1996). Outrageous aphid population often results in stunting and curling of leaves, reduces plant vigour rendering the plant more susceptible to secondary infestation which may exterminate the plant completely (Berlandier and Sweetingham, 2003).
Population dynamics studies are imperative for proper knowledge of pest ecology in key agricultural crops. Aphids as well as their predators are affected by prevailing weather factors viz., temperature, relative humidity, rainfall, sunshine, and wind speed. Favourable weather conditions help in population build-up and ultimately increases pest infestation. (Khokhar et al., 2019). Aphids are being widely studied in several crops, but little is known about population dynamics and its predatory complex in tomato. An exact determination of changes in aphid and its predators' population with meteorological factors is a prime requisite for Integrated Pest Management (IPM). We aimed to utilize these research gaps and study the population dynamics of the aphid complex and its predators in tomato. Based on the literature review, we hypothesized that prevailing weather conditions greatly influence the aphid population which in turn might affect its predators and their feeding rates. This study explains the trends in aphid and their predators' population and helps us to predict the crop stages when pest management tactics can be initiated. 


\section{MATERIALS AND METHODS}

This experiment was conducted at University Research Area of, CCS Haryana Agricultural University, Hisar during Rabi seasons of 2016-17 and 2017-18. Seedlings of tomato crop $c v$. Selection-7 were transplanted in a flatbed of $100 \mathrm{~m}^{2}$ by adopting $60 \mathrm{~cm} \times 45 \mathrm{~cm}$ spacing in 2nd week of February 2017 and 2018. The whole bed was divided into 4 quadrats of $25 \mathrm{~m}^{2}$ representing four replicates. The crop was raised as per the standard practices, recommended by CCS Haryana Agricultural University, except for the plant protection measures. Nymphs and adults of aphids were observed and counted at a weekly interval on three leaves per plant i.e., one leaf each from the top, middle and bottom of crop canopy, starting from 15 days after transplanting (DAT). Aphid population data were recorded on 10 randomly selected plants per quadrat during morning hours (06:30 to 08:00 AM) and expressed as aphids per three leaves per plant, irrespective of their species (Chavan et al 2013). Different spiders, maggots of syrphid fly and grubs and adults of coccinellids were counted at a weekly interval from each quadrat irrespective of their species and expressed as spiders, syrphid fly maggots and coccinellids per plant, respectively. Relation between aphids and their predators and different weather parameters were worked out by Pearson correlation coefficient, regression and PCA. Data on different weather parameters [maximum and minimum temperatures $\left({ }^{\circ} \mathrm{C}\right)$, morning and evening relative humidity $(\%)$, wind speed $(\mathrm{km} / \mathrm{hr})$, bright sunshine hours and total rainfall $(\mathrm{mm})$ ] were obtained from nearby Agrometeorological Observatory. Data under different heads were pooled for both seasons, Rabi 2016-2017 and 2017-2018. Correlation and regression analysis were done with IBM SPSS and PCA was plotted by R software (IBM SPSS, 2017; R core Team, 2017).

\section{RESULTS AND DISCUSSION}

\section{Aphid population in relation to weather parameters}

The tomato crop was infested by two dominant aphid species viz., Aphis gossypii and Myzus persicae. Aphid infestation started during the first week of March (9th SMW) and attained a peak (22.65 aphids per three leaves per plant) during the 4th week of March (12th SMW) (Table 1). Similar levels of aphid infestation during the early stages of crop growth have been reported earlier (Mandlio et al., 2015; This variation may be attributed to seasonal and environmental differences. Aphids population followed a declining trend during later stages of crop growth, and it was minimum ( 0.10 aphid per three leaves per plant) during the second week of May (19th SMW). No aphid population was observed afterwards (Table 1). Chavan et al., (2013) too also reported a steady decline in aphid population with crop maturity.

\section{Correlation and principal component analysis}

Aphid population exhibited highly significant negative correlation with minimum temperature $[\mathrm{r}=$ $-0.917^{* *}$; Bayes factor $\left.(\mathrm{BF})=0.002\right]$, maximum temperature $\left(\mathrm{r}=-0.895^{* *} ; \mathrm{BF}=0.005\right)$ and wind speed $\left(\mathrm{r}=-0.809^{* *} ; \mathrm{BF}=\right.$ 0.049). However, there was a significant positive correlation between aphid population and morning relative humidity $\left(\mathrm{r}=0.933^{*} ; \mathrm{BF}=0.001\right)$ and evening relative humidity $\left(\mathrm{r}=0.856^{* *} ; \mathrm{BF}=0.017\right)$ (Table 2). A similar type of correlation was reported in studies from other parts of India (Pavan et al., 2019). For instance, Deb and Bharpoda (2017) reported a significant negative correlation between aphid infestation and maximum temperature $(\mathrm{r}=-0.699 * *)$ and minimum temperature $\left(\mathrm{r}=-0.693^{* *}\right)$. However, Mondal et al., (2018) showed a non-significant correlation between aphid population and rainfall. A multivariate analysis was performed using PCA to reduce the dimensions of data and variables were transformed into principal components (PC) to explain the nature and extent of the relationships among different variables. Principal components are the newly generated variables constructed as linear combinations of the initial variables. These new variables (i.e., principal components) are uncorrelated and most of the information within the initial variables is squeezed or compressed into the first components (PCI and PC2). PC1 and PC2 capture 57.6 and $20.3 \%$ of the variability in data, respectively (Fig. 1a). It explains that negatively correlated variables i.e., wind speed, maximum and minimum temperature, rainfall and sunshine hours are positioned on the opposite quadrats whereas positively correlated variables (morning and evening relative humidity) are positioned on the same side of the axis. The distance between each vector component explains the significance of each variable i.e. lesser the distance more significant is the relation (Fig 1a). The length of the vector explains the variance due to that vector i.e. longer the vector length, the more is the variation caused by the vector (Fig. 1a). According to PC1 And PC2, weather parameters viz., maximum and minimum temperature, morning and evening relative humidity, wind speed, and biotic factors viz., syrphid fly maggots and coccinellids are the most important variables causing significant variability in aphids population (Fig. F1a). 
Table 1: Population dynamics of aphid complex and coexisting predators on tomato during Rabi, 2016-17 and 2017-18 (pooled)

\begin{tabular}{|c|c|c|c|c|c|c|c|c|c|c|c|}
\hline \multirow{3}{*}{$\mathrm{SMW}^{*}$} & \multirow{3}{*}{$\begin{array}{l}\text { Aphid } \\
\text { population } \\
\text { per three } \\
\text { leaves per }\end{array}$} & \multicolumn{3}{|c|}{ Predators population per plant } & \multicolumn{7}{|c|}{ Weather parameters } \\
\hline & & \multirow{2}{*}{$\begin{array}{l}\text { Coccinellids } \\
\text { grubs and } \\
\text { adults }\end{array}$} & \multirow[t]{2}{*}{ Spiders } & \multirow{2}{*}{$\begin{array}{l}\text { Syrphid } \\
\text { fly } \\
\text { maggots }\end{array}$} & \multicolumn{2}{|c|}{$\begin{array}{c}\text { Temperature } \\
\left({ }^{\circ} \mathrm{C}\right)\end{array}$} & \multicolumn{2}{|c|}{ RH (\%) } & \multirow{2}{*}{$\begin{array}{l}\text { Rainfall } \\
\text { (mm) }\end{array}$} & \multirow{2}{*}{$\begin{array}{l}\text { Sunshine } \\
\text { hrs./day }\end{array}$} & \multirow{2}{*}{$\begin{array}{c}\text { Wind } \\
\text { speed } \\
\left(\mathrm{km} \mathrm{hr}^{-1}\right)\end{array}$} \\
\hline & & & & & Tmax & Tmin & Morning & Evening & & & \\
\hline 9 & p5.75 & 0.25 & 0.10 & 1.85 & 27.51 & 10.20 & 91.71 & 42.07 & 0.00 & 7.45 & 2.76 \\
\hline 10 & 19.00 & 0.50 & 0.60 & 2.80 & 27.25 & 10.12 & 87.45 & 40.84 & 0.55 & 7.39 & 3.56 \\
\hline 11 & 21.50 & 0.61 & 1.06 & 3.90 & 28.46 & 10.05 & 85.07 & 35.43 & 0.00 & 7.80 & 2.60 \\
\hline 12 & 22.65 & 0.69 & 1.11 & 4.35 & 30.93 & 13.05 & 86.00 & 37.86 & 0.00 & 7.95 & 2.95 \\
\hline 13 & 15.30 & 0.79 & 0.93 & 4.25 & 35.49 & 15.25 & 79.00 & 28.79 & 0.00 & 8.73 & 3.19 \\
\hline 14 & 10.70 & 0.72 & 0.76 & 3.85 & 35.74 & 18.61 & 64.50 & 30.43 & 0.00 & 6.28 & 6.55 \\
\hline 15 & 6.40 & 0.61 & 0.74 & 3.10 & 35.42 & 16.02 & 65.72 & 27.43 & 1.00 & 8.64 & 4.61 \\
\hline 16 & 2.70 & 0.65 & 0.60 & 1.90 & 40.29 & 21.08 & 50.79 & 25.00 & 0.00 & 9.08 & 4.75 \\
\hline 17 & 1.35 & 0.46 & 0.50 & 0.85 & 38.89 & 20.66 & 52.93 & 25.36 & 0.07 & 8.19 & 5.12 \\
\hline 18 & 0.50 & 0.25 & 0.45 & 0.45 & 39.13 & 23.13 & 57.00 & 26.43 & 0.00 & 7.50 & 7.05 \\
\hline 19 & 0.10 & 0.10 & 0.37 & 0.15 & 40.88 & 23.61 & 56.00 & 23.14 & 0.10 & 7.85 & 5.95 \\
\hline 20 & 0.00 & 0.05 & 0.23 & 0.00 & 40.54 & 24.69 & 56.00 & 31.57 & 0.00 & 6.83 & 6.15 \\
\hline 21 & 0.00 & 0.00 & 0.09 & 0.00 & 41.67 & 24.27 & 52.43 & 24.64 & 0.00 & 8.42 & 4.56 \\
\hline 22 & 0.00 & 0.00 & 0.05 & 0.00 & 40.96 & 25.57 & 70.07 & 41.43 & 2.20 & 7.86 & 8.42 \\
\hline
\end{tabular}

*SMW $=$ Standard Meteorological Week

Table 2: Bayesian inference about Pearson correlation coefficient of aphid complex and coexisting predators with weather parameters

\begin{tabular}{|c|c|c|c|c|c|c|c|c|}
\hline \multirow[t]{2}{*}{ Weather parameters } & \multicolumn{2}{|c|}{$\begin{array}{l}\text { Aphid population } \\
\text { per } \\
3 \text { leaves per plant }\end{array}$} & \multicolumn{2}{|c|}{$\begin{array}{l}\text { Coccinellids per } \\
\text { plant }\end{array}$} & \multicolumn{2}{|c|}{ Spiders per plant } & \multicolumn{2}{|c|}{$\begin{array}{c}\text { Syrphid fly } \\
\text { maggots per plant }\end{array}$} \\
\hline & $\mathrm{r}$ & $\begin{array}{l}\text { Bayes } \\
\text { factor }\end{array}$ & $\mathrm{r}$ & $\begin{array}{l}\text { Bayes } \\
\text { factor }\end{array}$ & $\mathrm{r}$ & $\begin{array}{l}\text { Bayes } \\
\text { factor }\end{array}$ & $\mathrm{r}$ & $\begin{array}{l}\text { Bayes } \\
\text { factor }\end{array}$ \\
\hline Maximum temperature & $-0.895 * *$ & 0.005 & $-0.310^{\mathrm{NS}}$ & 2.863 & $-0.464^{\mathrm{NS}}$ & 1.233 & $-0.547^{\mathrm{NS}}$ & 0.967 \\
\hline Minimum temperature & $-0.917 * *$ & 0.002 & $-0.471^{\mathrm{NS}}$ & 1.397 & $-0.576^{*}$ & 0.493 & $-0.653^{*}$ & 0.415 \\
\hline Morning relative humidity & $0.933 * *$ & 0.001 & $-0.434^{\mathrm{NS}}$ & 1.707 & $0.371^{\mathrm{NS}}$ & 2.123 & $0.611 *$ & 0.601 \\
\hline Evening relative humidity & $0.856^{* *}$ & 0.017 & $0.072^{\mathrm{NS}}$ & 4.543 & $-0.19^{\mathrm{NS}}$ & 4.978 & $0.466^{\mathrm{NS}}$ & 1.556 \\
\hline Wind speed & $-0.809 * *$ & 0.049 & $0.304^{\mathrm{NS}}$ & 2.921 & $-0.511^{\mathrm{NS}}$ & 0.875 & $-0.571^{\mathrm{NS}}$ & 0.819 \\
\hline Rainfall & $-0.042^{\mathrm{NS}}$ & 4.452 & $0.131^{\mathrm{NS}}$ & 4.286 & $-0.306^{\mathrm{NS}}$ & 2.829 & $0.084^{\mathrm{NS}}$ & 4.349 \\
\hline Sunshine hours & $-0.206^{\mathrm{NS}}$ & 3.714 & $0.368^{\mathrm{NS}}$ & 2.310 & $0.14^{\mathrm{NS}}$ & 4.450 & $-0.370^{\mathrm{NS}}$ & 4.458 \\
\hline
\end{tabular}

r: Pearson correlation coefficient; $\mathrm{NS}=$ non-significant $*=$ significant at $\mathrm{p}<0.05 ; * *=$ significant at $\mathrm{p}<0.01$

\# Bayes factor: null hypotheses $\left(\mathrm{H}_{0}\right)$ to alternate hypotheses $\left(\mathrm{H}_{1}\right)$; Bayes factor $<0.001$ : Extreme evidence for rejection of $\mathrm{H}_{0}$; $0.001<$ Bayes factor $<0.03$ : Very strong evidence for rejection of $\mathrm{H}_{0} ; 0.03<$ Bayes factor $<0.1$ : Strong evidence for rejection of $\mathrm{H}_{0} ; 0.1<$ Bayes factor $<0.33$ : Moderate evidence for rejection of $\mathrm{H}_{0} ; 0.33<$ Bayes factor $<1$ : Anecdotal evidence of rejection of $\mathrm{H}_{0}$; Bayes factor $=1$ : No evidence for rejection of $\mathrm{H}_{0} ; 1<$ Bayes factor $<3$ : Anecdotal evidence for acceptance of $\mathrm{H}_{0} ; 3<\mathrm{Bayes}$ factor $<10$ :Moderate evidence for acceptance of $\mathrm{H}_{0}$.

\section{Regression analysis}

Analysis of variance suggests significant individual effect of maximum temperature $\left(\mathrm{R}^{2}=0.80 ; \mathrm{F} 1,11=36.25\right.$; $\mathrm{p}=0.0002 * * *), \quad$ minimum temperature $\quad\left(\mathrm{R}^{2}=0.84\right.$; $\mathrm{F} 1,11=47.43 ; \mathrm{p}<0.0001 * * *)$, morning relative humidity $\left(\mathrm{R}^{2}=0.87 ; \mathrm{F} 1,11=60.37 ; \mathrm{p}<0.0001 * * *\right)$, evening relative humidity $\left(\mathrm{R}^{2}=0.73 ; \mathrm{F} 1,11=24.77 ; \mathrm{p}=0.0007 * * *\right)$, wind speed $\left(\mathrm{R}^{2}=0.65 ; \mathrm{F} 1,11=17.07 ; \mathrm{p}=0.003 * *\right)$ towards aphid population changes (Table 3$)$. Additionally, rainfall $(\mathrm{F} 1,11=$ $0.016 ; \mathrm{p}=0.903)$ and sunshine hours $\left(\mathrm{R}^{2}=0.04, \mathrm{~F} 1,11=0.399\right.$, $\mathrm{p}=0.543$ ) had minimal and non-significant individual effect (Table 3). However, the stepwise regression analysis was carried out to ascertain contribution of most significant weather variables. Morning relative humidity was the most 
Table 3: Linear model describing the effect of individual weather parameter on aphids and their predator complex population

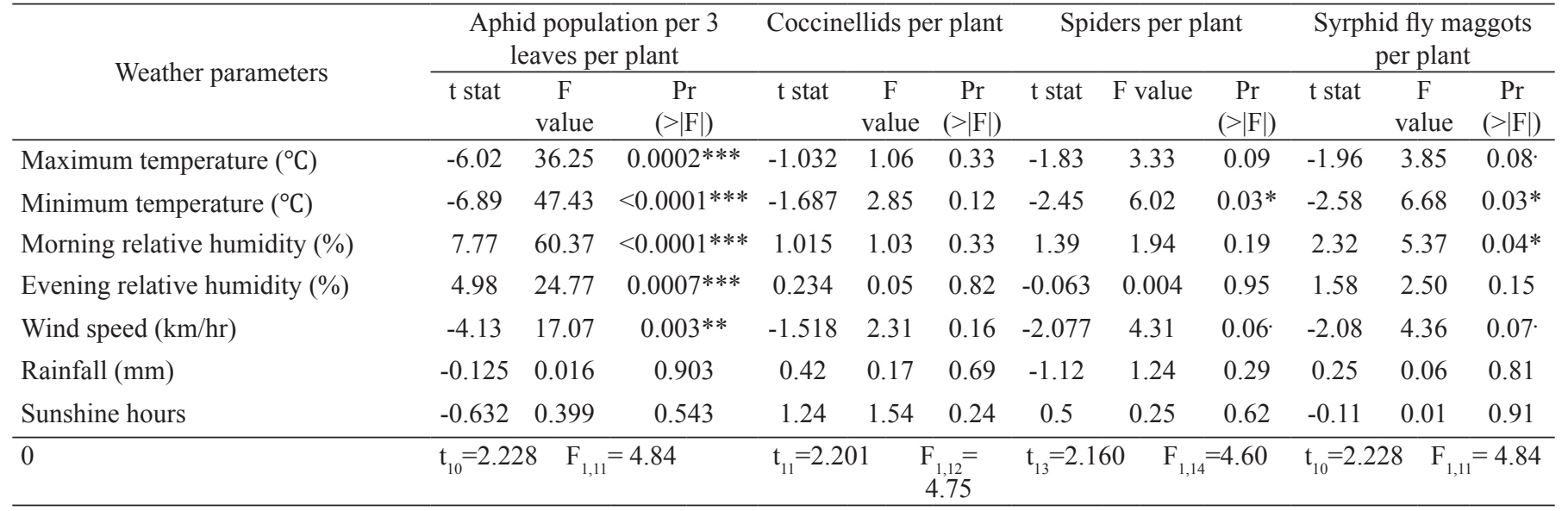

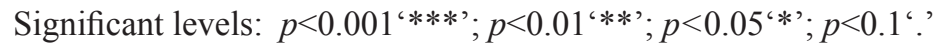

$P<0.001$ : extreme evidence against $\mathrm{H}_{0} ; p<0.01$ : very strong evidence against $\mathrm{H}_{0} ; 0.01<=p<0.05$ : moderate evidence against $\mathrm{H}_{0}$; $0.05<=p<0.10$ : suggestive evidence against $\mathrm{H}_{0} ; p>=0.10$ : little or no real evidence against $\mathrm{H}_{0}$

significant factor contributing 87 per cent variability (Table 4). Likewise, significant contribution of weather parameters has also been reported (Sharma et al., 2013).

\section{Predators population in relation to weather parameters}

Coccinellids : Three species of coccinellids viz., Brumoides suturalis, Cheilomenes sexmaculata, Coccinella septempunctata were observed feeding on aphids. Initially, the predator population was low but increased sustainably with an increase in the aphid population. Coccinellids were first observed during the first week of March (9th SMW) ( 0.25 grubs and adults per plant) and thereafter, attained peak during the first week of April (13th SMW) (0.79 grubs and adults per plant)(Table 1). Afterwards, coccinellids populations decreased gradually due to a reduction in prey density which continued up to 20th SMW (0.05 grubs and adults per plant) (Table 1). A similar period of activity was also recorded by Saljoqi et al., (2009). Coccinellids exhibited a non-significant correlation with all the weather parameters under study (Fig 1b \& Table 2). Kalasariya and Parmar (2018) and Subba (2013) as well recorded a non-significant correlation between coccinellids and weather parameter. Regression model suggests that maximum temperature and minimum temperature were primarily responsible for changes in coccinellids population (Table 4), however, the contribution was non-significant $(\mathrm{F} 1,12=1.06 ; \mathrm{p}=0.33$ \& $\mathrm{F} 1,12=2.85 ; \mathrm{p}=0.12$ ) (Table 3).

Spiders : Spiders are generalist predators which largely feed on sucking pests such as aphids as well as various lepidopteran pests recorded in the tomato ecosystem. Spiders were present during the entire crop period starting from 9th SMW to 22nd SMW (Table 1). The population started increasing from 9th SMW ( 0.10 spiders per plant) and peaked during the 4 th week of March (12th SMW) (1.11 spiders per plant) which are in accordance with previous findings (Subba, 2013). It showed a significant negative correlation with minimum temperature $\left(\mathrm{r}=-0.576^{*} ; \mathrm{BF}=0.493\right)$ but it was non-significantly correlated with all the other weather parameters (Fig 1c \& Table 2) (Subba, 2013). In contrast, a positive correlation with temperature and sunshine hours; negative correlation with minimum relative humidity, average relative humidity and rainfall has been reported (Patel et al., 2005).

Syrphid fly maggots : Syrphid fly maggots are important predators in tomato crop and actively feed on nymphs of aphid. The initial population was recorded during the first week of March (9th SMW) (1.85 syrphid fly maggots per plant) and attained a peak (4.35 syrphid fly maggots per plant) during the last week of March (12th SMW). Afterwards, it showed a declining trend with a decrease in aphid population and no population was recorded after the second week of May (19th SMW) (Table 1). Syrphid fly maggot population was significantly and negatively correlated with minimum temperature $\left(\mathrm{r}=-0.653^{* *} ; \mathrm{BF}=0.415\right)$ whereas it exhibited a significant positive correlation with morning relative humidity $\left(\mathrm{r}=0.611^{*} ; \mathrm{BF}=0.601\right)($ Fig $1 \mathrm{~d} \&$ Table 2). Literature concerning population dynamics of syrphid fly maggot in tomato crop is scarce. However, maggot population was 

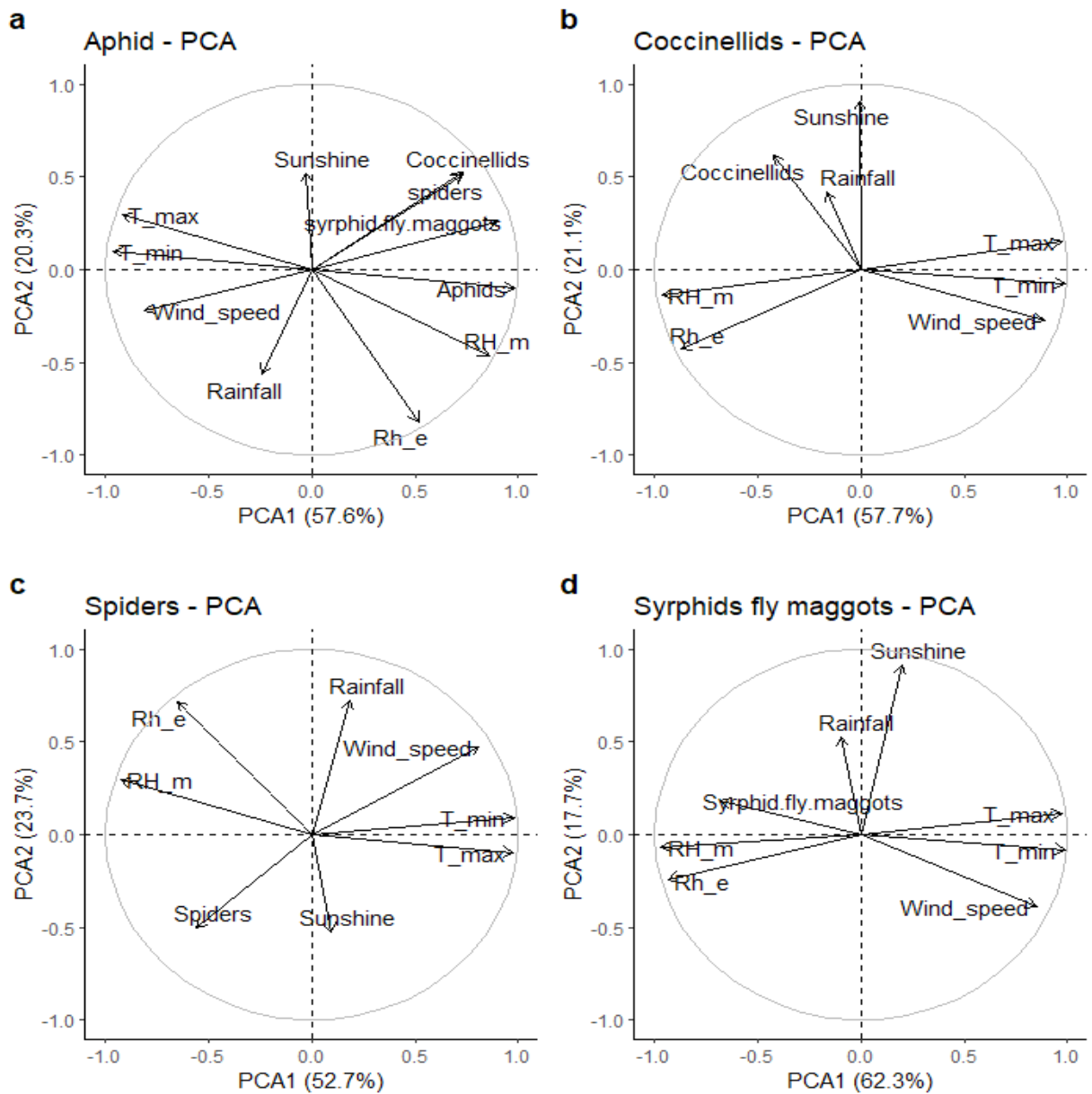

Fig. 1: Loading plots of aphid population with weather parameters and predators (a), coccinellids (b), spider (c) and syrphid fly maggots (d) with weather parameters. The length of vector and angles between the component vectors indicates how a characteristic correlate with another.

Table 4: Stepwise linear regression of aphid and coexisting predators with weather parameters (Pooled)

\begin{tabular}{lcc}
\hline \multicolumn{3}{c}{ Stepwise linear regression } \\
\hline Aphid (Y1) & $\mathrm{Y} 2=-26.45+0.52 \mathrm{X} 3$ & 0.87 \\
Coccinellids (Y2) & $\mathrm{Y} 2=-1.49+0.12 \mathrm{X} 1-0.13 \mathrm{X} 2$ & 0.59 \\
Spiders (Y3) & $\mathrm{Y} 3=1.19-0.04 \mathrm{X} 2$ & 0.33 \\
Syrphid fly maggots (Y4) & $\mathrm{Y} 4=5.69-0.19 \mathrm{X} 2$ & 0.42 \\
\hline
\end{tabular}

$\mathrm{X} 1$ : Maximum temperature $\left({ }^{\circ} \mathrm{C}\right) ; \mathrm{X} 2$ : Minimum temperature $\left({ }^{\circ} \mathrm{C}\right)$; X3: Morning relative humidity $(\%)$

positively correlated with temperature on the mustard crop (Dwivedi et al., 2018). Step-wise regression equation shows that minimum temperature was the most significant factor among all $\left(\mathrm{R}^{2}=0.43 ; \mathrm{F} 1,11=6.68 ; \mathrm{p}=0.03 *\right)$ (Table 3 and 4$)$.

\section{Predators population in relation to pest density}

The predators' population showed an increasing trend with build-up in the aphid population stating a positive
Table 5: Correlation coefficient between aphid and natural enemies (Pooled)

\begin{tabular}{lcc}
\hline \multirow{2}{*}{ Predators } & \multicolumn{2}{c}{$\begin{array}{c}\text { Aphid population per three } \\
\text { leaves per plant }\end{array}$} \\
\cline { 2 - 3 } & $\mathrm{r}$ & $\begin{array}{c}\text { Bayes factor } \\
\text { (BF)\# }\end{array}$ \\
\hline Syrphid fly maggots per plant & $0.855^{* *}$ & 0.003 \\
Coccinellids grubs and adults per plant & $0.682^{* *}$ & 0.236 \\
Spiders per plant & $0.642^{*}$ & 0.139 \\
\hline
\end{tabular}

correlation (Table 1). Population of coccinellids, spiders and syrphid fly maggots exhibited highly significant and positive correlation with aphid population with $\mathrm{r}=0.642 *, \mathrm{r}=0.682 * *$, $\mathrm{r}=0.855^{* *}$, respectively (Table 5). Similarly, a significant positive correlation has been reported between spiders $(\mathrm{r}=0.786)$, coccinellids $(\mathrm{r}=0.933)$ and aphid population (Nayak et al., 2019). Information about the correlation of syrphid fly maggots with aphid population on tomato crop is 
scanty while Devi et al. (2011) reported a significant positive correlation $(\mathrm{r}=0.867)$ between aphid and syrphid fly maggot population on cabbage. Ranila et al., (2015) too reported a significant positive correlation between aphid population and biotic factors viz., coccinellids and syrphids on coriander.

\section{Predicting pest population}

Based on our results, the most important variables contributing significantly towards the variance in the pest population were maximum and minimum temperature, morning relative humidity, wind speed and syrphids accounting for 99 per cent variability in the aphid population $\left(\mathrm{R}^{2}=0.99, \mathrm{~F}=137.39 ; \mathrm{P}<0.001\right)$. The linear regression equation thus developed for prediction of pest population is:

$\mathrm{Y}=39.21-2.13 \mathrm{Tmax}+2.10 \mathrm{Tmin}+0.16$ Morning RH -2.10 Wind speed +3.14 Syrphids

\section{CONCLUSION}

Aphid population was higher during the early stage of crop growth suggesting the need for pest management during the initial vegetative stage which was largely influenced by prevailing meteorological parameters and predators. Aphid population has a highly significant negative correlation with wind speed, maximum and minimum temperature whereas a highly significant positive correlation with morning and evening relative humidity. Furthermore, the population of predators viz., coccinellids, spiders and syrphid fly maggots exhibit a highly significant positive correlation with prey population suggesting a positive density-dependent response. Thorough knowledge of population dynamic studies of tomato aphid complex in relation to abiotic and biotic factors may strengthen the development of efficient pest management strategies. A holistic IPM program can be designed against aphid complex in tomato where predators can be used in conjugation with other control strategies. This may reduce the dependence on pesticides and may reduce the problems associated with indiscriminate pesticide usage.

\section{REFERENCES}

Berlandier, F.A. and Sweetingham, M.W. (2003). Aphid feeding damage causes large losses in susceptible lupine cultivars. Australian J. Exp. Agric., 43(11):1357-1362.

Chavan, S.M., Kumar, S. and Arve, S.S. (2013). Population dynamics and development of suitable pest management module against major insect pests of tomato (Solanum lycopersicum). J. Appl. Hortic., 15(2):150-155.

Deb, S. and Bharpoda, T.M. (2017). Impact of meteorological factors on population of major insect pests in tomato, Lycopersicon esculentum Mill. under middle Gujarat condition. J. Agrometeorol., 19(3):251-254.

Devi, Y.R., Kalita, J. and Singh, T.K. (2011). Biological control potential of an aphidophagous syrphid, Episyrphus balteatus, De-Geer (Diptera: Syrphidae) on mustard aphid, Lipaphis erysimi (Kalt.) (Homoptera: Aphididae) on cabbage ecosystem in Manipur. J. Exp. Sci., 2(12):13-16.

Dwivedi, S.A., Singh, R.S. and Gharde, S.K. (2018). Populations buildup of mustard aphid and their natural enemies in relation to biotic and abiotic factors. Plant Arch., 18(2):2495-2500.

Faostat. (2018). Statistical databases. Food and Agriculture Organization of the United Nations. http://www.fao. org/faostat/tomato.

IBM Corp. Released 2017. IBM SPSS Statistics for Windows, Version 25.0. Armonk, NY: IBM Corp.

Kalasariya, R.L. and Parmar K.D. (2018). Effect of weather factors on population fluctuations of mustard aphid using path coefficient analysis. $J$. Agrometeorol., 20(1):46-49.

Khokhar, S., Rolania, K., Singh, G. and Kumar, K. (2019). Influence of prevailing weather parameters on population dynamics of fruit borer, Helicoverpa armigera (Hübner) on tomato in Haryana. $J$. Agrometeorol., 21(2):193-196.

Mondal, B., Mondal, P., Das, A. and Bhattyacharyya, K. (2019). Seasonal incidence of different insect pests of tomato (Lycopersicon esculentum Mill.) and their correlation with abiotic factor in lateritic zone of West Bengal. J. Entomol. Zool. Stud., 7(1):14261430.

Nayak, A.K., Sarkar, A. and Bala, S.C. (2019). Studies on population fluctuation and effect of biotic and abiotic stresses on the population of Myzus persicae (Sulz.) infesting potato in the gangetic basin of West Bengal. J. Entomol. Zool. Stud., 7(1):14-20.

Osei, M.K., Akromah, R., Shilh, S.L and Green, S.K. (2010). Evaluation of Some tomato Germplasm for 
resistance to Tomato Yellow Leaf Curl Virus disease

(TYLCV) in Ghana. Asp. Appl. Biol., 96:315-323.

Patel, M.L., Patel, K.G. and Pandya, H.V. (2005) Correlation of spiders with weather parameters and insect pests of rice (Oryza sativa L.). Insect Environ., 11(1):2325 .

Pavan, T., Ghosh, S.K., Nihal, R. and Sri, N.R. (2019). Effect of abiotic factors on seasonal incidence and bioefficacy of some newer insecticides against aphid (Aphis gossypii) in tomato. J. Entomol. Zool. Stud., 7(3):513-516.

R Core Team, R. (2017). A language and environment for statistical computing. R Foundation for Statistical Computing, Vienna, Austria, https://www.R-project. org/.

Ranila, A., Kanani, M.K., Bhut, J.B. and Borad, P.K. (2015). Population dynamics of Aphis gossypii Glover on coriander in relation to biotic and abiotic factors. Int.
J. Plant Prot., 8(2):372-374.

Saljoqi, A.U.R., Khan, K. and Rehman, S. (2009). Integrated management of potato- peach aphid, Myzus persicae (sulzer). Sarhad J. Agric., 25(4):573-580Shakeel, M., Akram, W., Hamza, A., Ali, M.W. and Ali, A. (2014). Population dynamics of aphid (Aphis gossypii G.) on tomato agro-ecosystem in Faisalabad region. Int. J. Agric. Sci., 1(3):2348-3997.

Sharma, D., Maqbool, A., Ahmad, H. and Jamwal, V. V. S. (2013). Meteorological factors influencing insect pests of tomato. Ann. Pl. Protec. Sci., 21(1):68-71.

Subba. (2013). Studies on the pest complex of tomato (Lycopersicon esculentum L.) and their sustainable management. M.Sc. (Ag) Thesis, College of Agriculture, Pundibari, coochbehar, West Bengal, India.

Zalom, F.G. (2003). Pests, endangered pesticides, and processing tomatoes. Acta Hortic., 613:223-233. 